\title{
REDISCOVERY OF MALAXIS NANA (ORCHIDACEAE: MALAXIDEAE) IN COSTA RICA, WITH AN UPDATED DESCRIPTION
}

\author{
Oscar A. Pérez-Escobar ${ }^{1,4} \&$ Mario A. Blanco ${ }^{2,3}$ \\ ${ }^{1}$ Department of Botany, Systematics and Mycology, Ludwig-Maximilians Universität, \\ Menzinger Straße 65, Münich, Germany \\ ${ }^{2}$ Escuela de Biología, Universidad de Costa Rica, 11501-2060, San Pedro de Montes de Oca, \\ San José, Costa Rica \\ ${ }^{3}$ Research Associate, Jardín Botánico Lankester, Universidad de Costa Rica, \\ Apdo. 302-7050 Cartago, Costa Rica \\ ${ }^{4}$ Corresponding author: oapereze@yahoo.com
}

\begin{abstract}
Malaxis nana C. Schweinf. is known from two herbarium specimens collected in 1925 in San Ramón, Alajuela province, and three additional specimens without detailed locality data collected in the late 1800's, all of them in Costa Rica. This species had not been registered since. Malaxis nana is hereby first reported for Las Cruces Biological Station, Puntarenas province, in southern Costa Rica. An updated description, illustration, photographs and distribution map for this taxon are provided.
\end{abstract}

Resumen. Malaxis nana C. Schweinf. se conoce de dos especímenes recolectados en 1925 en San Ramón, provincia de Alajuela, y tres especímenes adicionales sin datos de localidad detallados y recolectados en los finales de los 1800 's, todos de Costa Rica. Esta especie no había sido registrada desde entonces. Aquí informamos por vez primera sobre la existencia de Malaxis nana en la Estación Biológica Las Cruces, provincia de Puntarenas, en el sur de Costa Rica. Se presenta una descripción actualizada, ilustración, fotografías y mapa de distribución para este taxón.

Key words: Alberto M. Brenes, Auguste R. Endrés, Las Cruces Biological Station

Introduction. The genus Malaxis Sol. ex Sw. (1788: 119; Orchidaceae) encompasses ca. 300 species (Todzia 1995, Dodson 2002, Dressler 2003, Cribb 2005) distributed worldwide, with at ca. 100 species in the Western Hemisphere (Dodson 2002) and 21 reported so far for Costa Rica (Pupulin 2002, Dressler 2003). According to a preliminary molecular phylogenetic analysis (Cameron 2005) the genus is at least diphyletic in its traditional circumscription. Here, we adopt the generic classification of tribe Malaxideae Lindl. of Cribb (2005; 13 genera), as well as his circumscription of Malaxis. Szlachetko and Margońska (2006) recognize at least two generic segregates of Neotropical Malaxis sensu Cribb (2005) (i.e., Microstylis (Nutt.) Eaton and Tamayorkis Szlach.); however, their rationale is not explicit, and the species treated here would still be included in their narrow circumscription of Malaxis.

Tropical species of Malaxis occur in a great variety of environments, ranging from lowlands rain forests to paramos (and reportedly also from semiarid environments; González-Tamayo 2002), from sea level to 3500 m elevation (González-Tamayo 2002). Plants of Malaxis are easily recognized by their herbaceous, sympodial habit, rhizomatous stems often with small pseudobulbs or corms covered by membranaceous cataphylls, one or two non-articulated leaves produced per sympodial unit, terminal inflorescences (either racemes or corymbs), and small, usually green flowers with a frequently concave disc (sometimes transversally divided by a longitudinal ridge) located at the base of the labellum.

During the botanical field course "Sistemática de Plantas Tropicales (OET 2013-18)" at Las Cruces Biological Station (southern Fila Costeña, Puntarenas Province, Costa Rica), a small epiphytic plant of Malaxis was found growing in late secondary forest at the base of a mature tree with ca. $50 \mathrm{~cm}$ of diameter at breast height $(\mathrm{DBH})$; this plant was eventually identified as M. nana C. Schweinf. (1938: 89-91). 
After studying specimens from six herbaria in Costa Rica (CR, HLDG, INB, JBL, LSCR, and USJ) and other important herbarium databases available on-line (AMES, K, MO, NY and W), only three additional specimens of $M$. nana were found (Endres 138 and Endres s.n. [2 specimens], both at W, collected somewhere in Costa Rica between 1866 and 1874; see discussion).

Because of the dearth of information on Malaxis nana, we provide an updated description, illustrations, a distribution map, and brief commentaries on the ecology of this taxon.

Materials and methods. Live plants of Malaxis nana were collected on July 2013 in the forest preserve of Las Cruces Biological Station (see detailed locality data under "additional specimens examined", below). The identification was made using the treatment of Dressler (2003) and verified by comparing the plant with the protologue (Schweinfurth 1938). A dry herbarium specimen was prepared, and flowers were also preserved in liquid (70\% ethanol, $20 \%$ water, $10 \%$ glycerol). The updated description below was prepared based on all six collections of M. nana available to us (either as physical specimens or as digital images) by early 2014. Distribution maps were generated using DIVA-GIS.

\section{TAXONOMIC TREATMENT}

Malaxis nana C. Schweinf., Bot. Mus. Leafl. 5(6): 89-91. 1938. (Figs. 1, 2)

Type: —COSTA RICA. [Alajuela: San Ramón,] bois à San Pedro de San Ramón, epiphyte, de $7 \mathrm{~cm}$. haut., alt. 850 m, 27 June 1925, Brenes (96) 1301 (holotype: AMES [image!], mounted on same sheet as paratype).

Epiphytic, sympodial, cespitose herbs (usually with only 2 consecutive sympodial units present at any given moment), $2-6 \mathrm{~cm}$ tall (to the top of the inflorescence). Roots 1.0-1.9 $\mathrm{mm}$ in diameter, whitish, pilose, growing from the base of each pseudobulb. Pseudobulbs 5-13 × 4-6 mm, green, ellipsoid to ovoid, heteroblastic, covered by 1-2 membranaceous cataphylls $0.5-2.0 \mathrm{~cm}$ long. Leaves 2 per sympodial unit (produced from the apex of the pseudobulb), present only in the most recent sympodial unit, shortly pseudopetiolate; pseudopetioles (sheaths of the foliage leaves) U-shaped in cross section, 5-27 $\times$ 3-4 mm (folded), erect, enveloping each other and the inflorescence, forming a pseudostem that projects above the hidden pseudobulb; blades 13.0-68.0 $\times$ 2.1-36.0 $\mathrm{mm}$ (in flowering shoots), often slightly anisophyllous, horizontal to ascending, subopposite, broadly lanceolate to ovate, basally cuneate to round, apically acute, shiny green with crystalline texture adaxially, matte greyish green abaxially, herbaceous, 9-16 veined, the midvein impressed. Inflorescences 22-45 mm long (including peduncle), erect to arcuate; peduncle $23-41 \mathrm{~mm}$ long, minutely ribbed, of a single visible internode; rachis $2-4 \mathrm{~mm}$ long, corymbose, with up to 25 simultaneously open flowers and ca. 12 developing buds. Floral bracts up to $2 \times$ $1 \mathrm{~mm}$, spreading, membranaceous, green, triangular, 1-veined. Pedicel plus ovary 5-15 mm long, seemingly increasing in length with age during both before and during anthesis. Flowers relatively big for the size of the plant (open perianth ca. $9 \mathrm{~mm}$ long), secondarily non-resupinate (by 180 degree twisting and upward bending of the pedicel), emerald green, turning coppery orange when old (or "chestnut brown" according to one herbarium collection), membranaceous, sepals and petals lustrous and somewhat translucent. Dorsal sepal $6.0-7.6 \times 1.2-2.0 \mathrm{~mm}$, spreading, adpressed to the ovary, narrowly lanceolate, acute to longacuminate, entire, retrorse towards the apex, 3-veined. Lateral sepals $6.1-8.0 \times 1.8 \mathrm{~mm}$, free, spreading, obliquely narrowly lanceolate, acute to acuminate, entire, margins slightly revolute, 3-veined. Petals 6.0$7.0 \times 0.5-1.0 \mathrm{~mm}$, spreading, slightly recurved upon the middle part, narrowly triangular to linear, acute, entire, 1-veined. Labellum 5.1-6.5 × 2.1-4.0 mm, spreading, ovate to lanceolate, long-acuminate, entire, fleshy, concave at the proximal half, disc cavity nondivided, somewhat darker than the rest of the labellum. Column $1.1 \times 2.0 \mathrm{~mm}$ (wider than long), dorsiventrally compressed, emarginate. Anther dorsal, with 2 divergent thecae. Pollinia 4 in 2 hemipollinaria (1 per theca), each pollinium ca. $1 \mathrm{~mm}$ long, yellow, narrowly ovoid; the two pollinia in each hemipollinarium tightly appressed to each other, sharing a single apical caudicle ca. $0.2 \mathrm{~mm}$ long. Rostellum concave. Stigma ventral, transversally bilobed, ca. $0.7 \times 1.5 \mathrm{~mm}$. Fruit a capsule, $5 \mathrm{~mm}$ long when dehisced, apparently with 2 narrow valves and 1 wider valve separating at apex. 

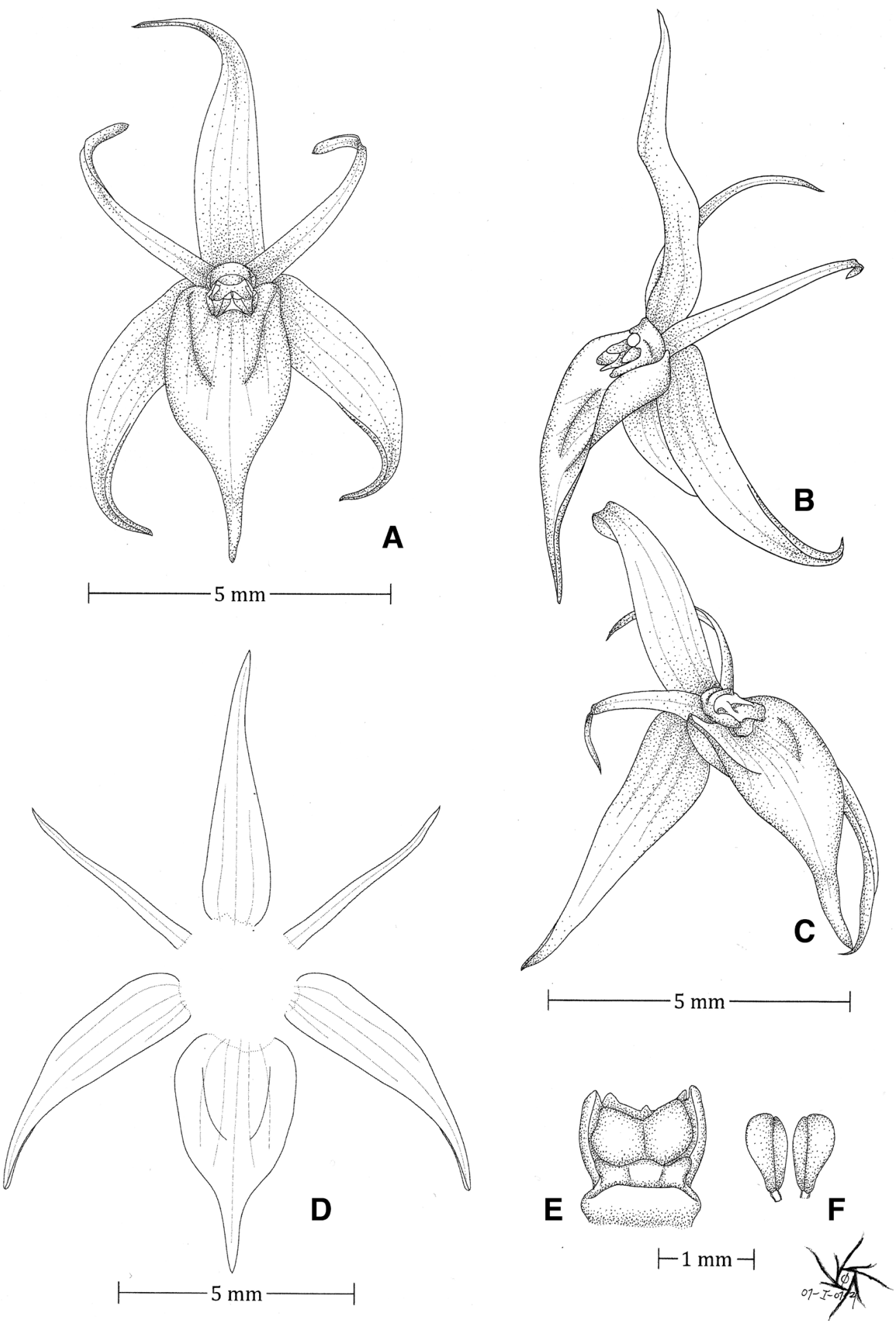

FiguRe 1. Malaxis nana. A. Flower, front view. B. Flower, side view. C. Flower, oblique view. D. Dissected perianth. E. Column, dorsal view, with hemipollinaria removed. F. Hemipollinaria. Drawn by O. Pérez from Pérez 1412. 

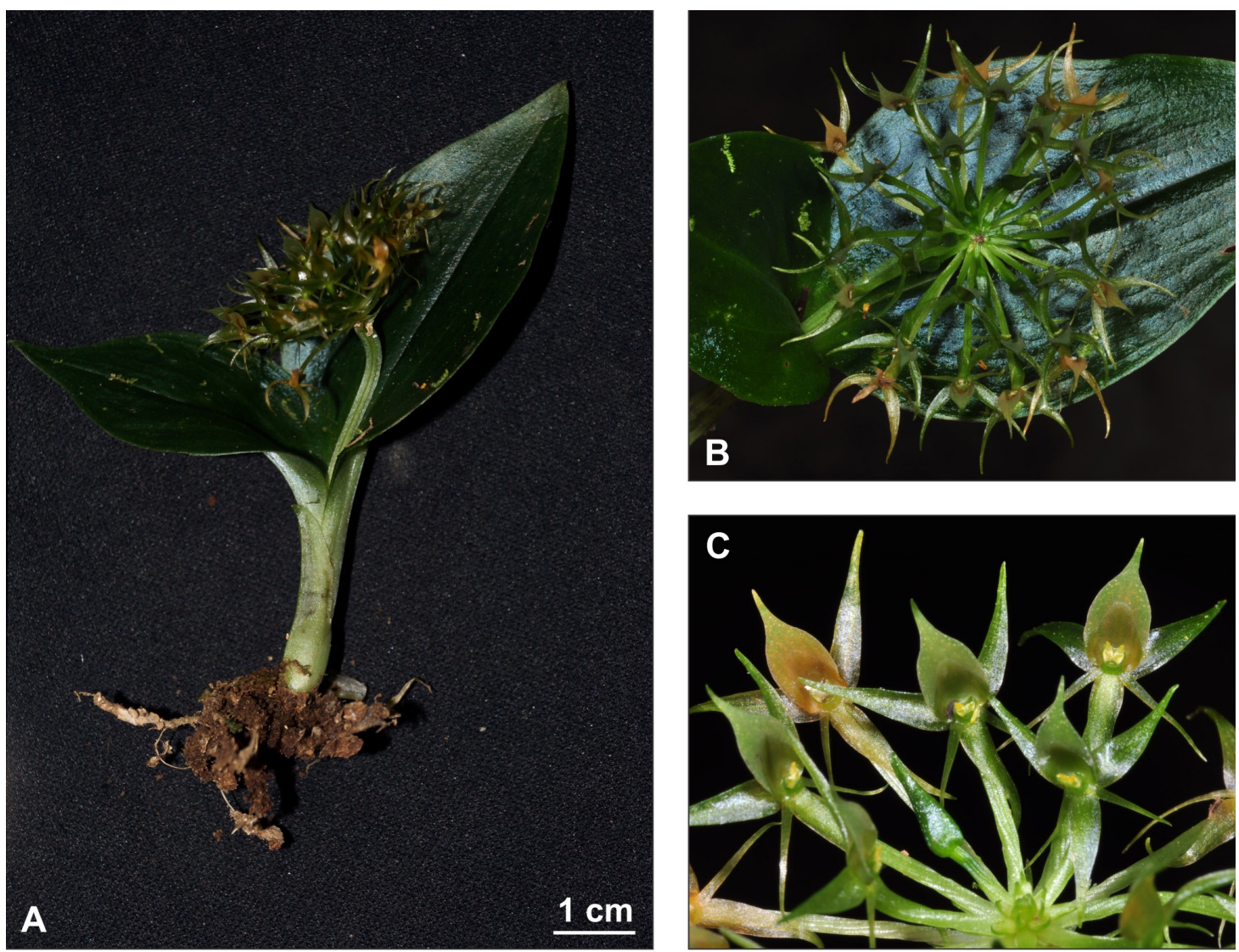

FiguRE 2. Malaxis nana. A. Plant habit. B. Inflorescence, top view. C. Flowers, top view. Note flowers secondarily nonresupinate by the 180 degree twisting and upward bending of the pedicels, and the old flowers turning yellowish orange. Photos by M. A. Blanco \& O. Pérez.

Additional specimens examined: COSTA RICA. Without additional data: Endrés s.n. (W no. 188939091, image!), 1867, Endrés 138 (W no. 19521 [image!] \& 1889-40326 [image!]). [Alajuela: San Ramón,] Bosquet du Cerro de San Isidro de San Ramón, 1175 m, 10 July 1925, Brenes (131) 1334 (AMES [image!, mounted on same sheet as holotype], CR!). Puntarenas: Coto Brus, San Vito, Estación Biológica Las Cruces, sendero Río Java, 1200 m, lat.: 8.786788 , long.: $-82.965540^{\circ}$, 14 July 2013, Pérez 1412 (USJ!, JBL-liquid!).

Distribution AND ECOlogy: Malaxis nana is considered endemic to Costa Rica and so far it is known only from Alajuela Province, San Ramón County (type locality and San Isidro Hill) and Puntarenas Province, Coto Brus County (Las Cruces Biological Station) (Fig. 3). The last locality is only $6 \mathrm{~km}$ away from the
Panamanian border; thus, it is highly likely that the species also occurs in Panama.

Plants of Malaxis nana grow as epiphytes in the lower strata of premontane wet forests, in an elevational range of 850-1200 m. In Las Cruces Biological Station, plants of M. nana were observed growing on mature trees of ca. $50 \mathrm{~cm} \mathrm{DBH}$. When the present manuscript was in press, we learned that $M$. nana was collected again in Las Cruces Biological Station in June 2014, this time during the course "Tropical Plant Systematics" (voucher: Bonifacino \& Damián 5001, to be deposited at USJ; verified by photos of the live plant sent to us), apparently from the very same colony as Pérez 1412. Flowering plants have been collected at least in June and July (the Endrés specimens do not indicate a collecting date).

COMMENTARY: Malaxis nana was described by Charles Schweinfurth (1938: 89-91) from a plant collected 


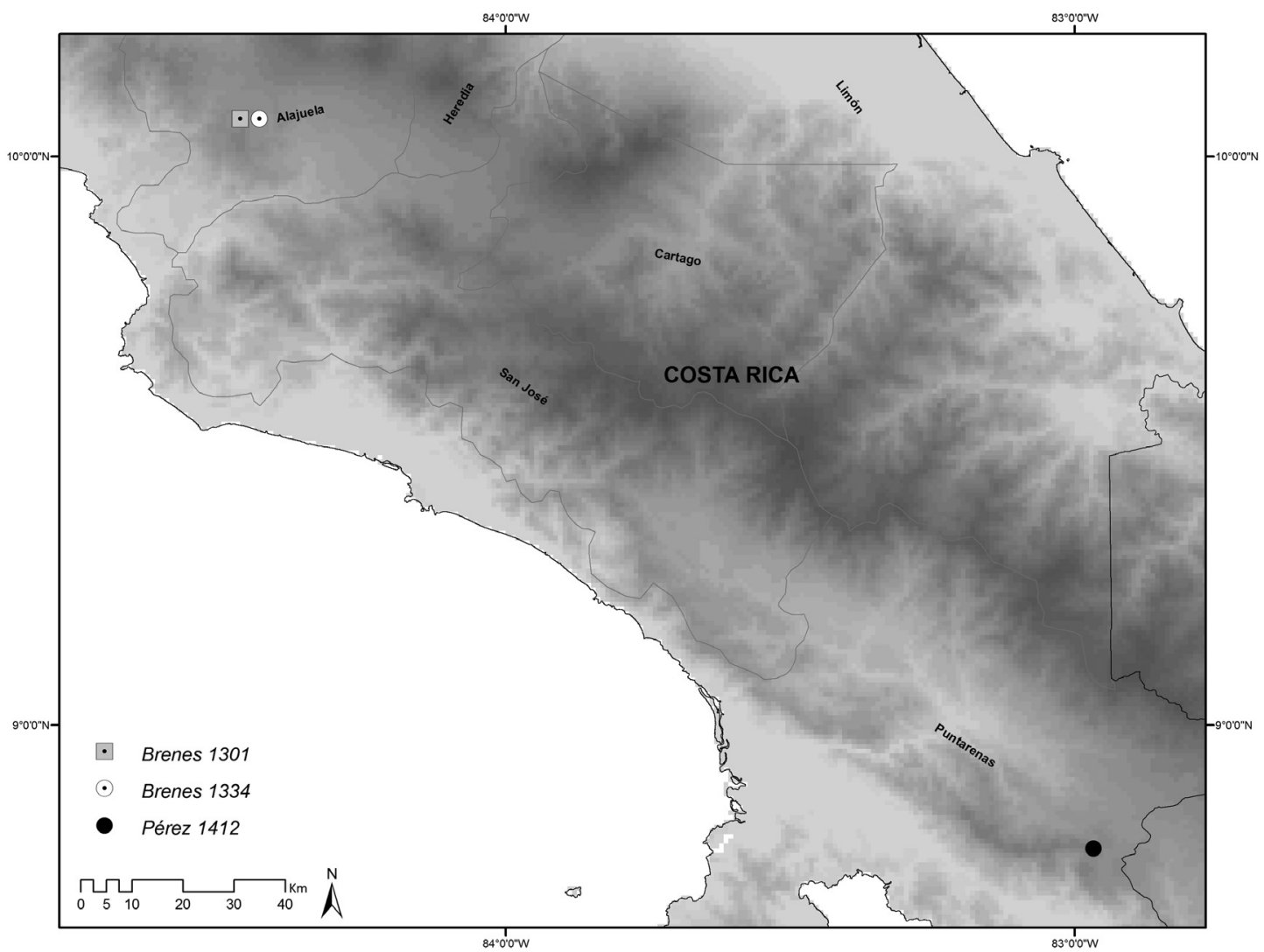

FIGURE 3. Distribution of Malaxis nana (based on available herbarium specimens with locality data)

in San Ramón county, Alajuela province, and from another record from a nearby locality (San Isidro Hill); both plants were collected by Alberto M. Brenes (for information about Brenes's collecting activities and the numbering of his collections see Barringer 1986). Three other herbarium specimens (unknown to Schweinfurth) were collected by Auguste R. Endrés in Costa Rica sometime between 1866 and 1874 (during his stay in that country; Ossenbach et al. 2010) - at least two of them in 1867 (see below). Endrés sent his specimens to H.G. Reichenbach in Hamburg, and they are currently deposited in the herbarium of the Naturhistorische Museum in Vienna (W). These three specimens lack additional locality information; however, they were possibly collected in the region of San Ramón, where Endrés lived during most of his time in Costa Rica (Ossenbach et al. 2010). Like many other collections that Endrés sent to Reichenbach, these represented a then-undescribed species but Reichenbach never described it (see
Pupulin et al. 2011). They were identified as Malaxis nana by Robert L. Dressler in 2001. Images of these and other Endrés collections are available through the Virtual Herbaria website (http://herbarium.univie. ac.at/database/search.php).

Two of the Endrés specimens have attached pieces of rag paper with the handwritten annotation "1867 [...] N $\mathrm{N}^{\circ} 138$ Microstylis - fls. chestnutbrown (concolored)". The first number probably refers to the year of collection. The second number is the "species number"; Endrés did not use collection numbers in the modern sense (i.e., to designate gatherings), but he used these numbers to correlate drawings and descriptions with plants that in his opinion belonged to the same species (Pupulin et al. 2011). It is interesting that the flowers of these specimens were described as "chestnut brown", in contrast to the plant from Las Cruces, which had green flowers. None of the two Brenes collections have a description of the flower color. 
In spite of more or less constant and intensive botanical explorations in Costa Rica ever since, no additional collections of this species were known until now. After 73 years of its description, hereby another population is reported, growing on a premontane wet forest from Puntarenas province, Coto Brus County (ca. $220 \mathrm{~km} \mathrm{SE}$ from the type locality). Malaxis nana can be recognized from other Costa Rican congeners by the small size of the plant, very short pseudobulbs bearing two leaves each, very short rhizome segments, thyrsoid inflorescences, relatively large flowers, the entire, acuminate labellum without auricles or lobes at the base, and the non divided disc cavity.

Acknowledgements. We thank the Organization of Tropical Studies for the logistical support provided for the course "Sistemática de Plantas Tropicales, OET 2013-18", during which the plant of Malaxis nana was documented. To the curators of the herbaria CR, INB, JBL, LSCR and USJ, for making specimens available for study. To Alexander Damián Loaiza for informing us of their collection of M. nana in Las Cruces Biological Station. Plants were collected under the permit number 026-2013-SINAC, granted by the Sistema Nacional de Áreas de Conservación to O.A. Pérez.

\section{LITERATURE CITED}

Barringer, K. 1986. Typification of Schlechter's Costa Rican Orchidaceae I. Types collected by A. Brenes. Fieldiana, Bot. n.s. 17: 1-24. https://archive.org/details/typificationofsc17barr

Cameron, K.M. 2005. Leave it to the leaves: A molecular phylogenetic study of Malaxideae (Epidendroideae, Orchidaceae). Amer. J. Bot. 92: 1025-1032. http://www.amjbot.org/content/92/6/1025.full

Cribb, P.J. 2005.Tribe Malaxideae. In: A. Pridgeon, P.J. Cribb, M.W. Chase \& F.N. Rasmussen (Eds.), Genera Orchidacearum, volume 4: Epidendroideae (Part One). Oxford University Press, Oxford, pp. 453-486.

Dodson, C.H. 2002. Native Ecuadorian Orchids, Volume III: Lepanthopsis-Oliveriana. Dodson Trust, Sarasota, 231 pp.

Dressler, R.L. 2003. Malaxis. In: Hammel, B.E., Grayum, M.H., Herrera, C. \& Zamora, N. (eds.) Manual de plantas de Costa Rica, Volumen III: Monocotiledóneas (Orchidaceae-Zingiberaceae). Monographs in Systematic Botany from the Missouri Botanical Garden 93: 269-277. http://www.botanicus.org/item/31753003149553

González-Tamayo, R. 2002. Malaxis (Orchidaceae), breve discusión de los rasgos específicos y dos taxones nuevos mexicanos. Ibugana 10(1-2): 67-75. ibugana.cucba.udg.mx/pdf/ibugana_10(1-2).pdf

Ossenbach, C., F. Pupulin \& R.L. Dressler. 2007. Orquídeas del Istmo Centroamericano: Catálogo y Estado de Conservación /Orchids of the Central American Isthmus: Checklist and Conservation Status. Editorial 25 de Mayo, Sabanilla, Montes de Oca.

Ossenbach, C., F. Pupulin \& R. Jenny. 2010. Orchid itineraries of Augustus R. Endrés in Central America: a biographic and geographic sketch. Lankesteriana 10: 19-47. http://www.epidendra.org/LITERATURE/Ossenbach\%20et\%20al\%20 2010/lit.html

Pupulin, F. 2002. Catálogo revisado y anotado de las Orchidaceae de Costa Rica. Lankesteriana 4: 1-88. http://www. epidendra.org/LITERATURE/Lit_Pupulin_2002b_Catalogo/lit.html

Pupulin, F., C. Ossenbach, R. Jenny \& E. Vitek. 2011. Typi Orchidacearum ab Augusto R. Endresio in Costa Rica lecti. Ann. Naturhist. Mus. Wien. Ser. B, Bot. Zool. 112: 265-313. http://www.epidendra.org/LITERATURE/Pupulin et al. 2011 - Endres typification/lit.html

Schweinfurth, C. 1938. New orchids from Central America. Bot. Mus. Leafl. [Harvard University] 5(6): 89-91. http://www. jstor.org/stable/41762660

Solander, D. \& O. Sawrtz. 1788. Malaxis. Nova Genera et Species Plantarum seu Prodromus 8: 119. http://www.botanicus. org/title/b1199485x

Szlachetko, D.L. \& H.B. Margońska. 2006. Redefinition of the genera Malaxis Sol. ex Sw. and Microstylis (Nutt.) Eaton (Orchidaceae, Epidendroideae). Acta Soc. Bot. Poloniae 75: 229-231.

Todzia, C.B. 1995. Malaxis chica, a new species of Orchidaceae from Nuevo León, Mexico. Brittonia 47: 24-26. http:// www.jstor.org/stable/2807244 